\title{
改良型簡易接合法を採用した既製コンクリート杭杭頭部の 高軸力下に打ける構造性能 \\ STRUCTURAL PERFORMANCE OF IMPROVED SIMPLIFIED CONNECTION SYSTEM AT PRECAST CONCRETE PILE HEAD UNDER HIGH AXIAL LOAD
}

\author{
青島一樹*1, 堀井良浩*2, 小林治男*3, 安達俊夫*4 \\ Kazuki AOSHIMA, Yoshihiro HORII, Haruo KOBAYASHI \\ and Toshio ADACHI
}

\begin{abstract}
An improved semi-rigid connection system which is used to connect a pile head and a pile cap has been proposed by authors and it has proved to be effective to reduce bending moment of a pile head under general level of axial load. However, in recent years, high bearing capacity piles, which have more than twice capacity of general piles, have become widely used. To investigate performances of the proposed system under such a high axial load, full-scale structural tests are conducted. From the test results, it is revealed that the maximum bending moment at a pile head $\left(M_{\max }\right)$ almost agrees with a maximum eccentric moment $\left(M_{e}\right)$ under low axial stress, but $M_{\max } / M_{e}$ decreases with axial stress increase. This paper proposes an experimental formula to evaluate $M_{\max }$ using $M_{e}$ and axial stress ratio ( $\sigma_{n} / \sigma_{B}$, $\sigma_{n}$ : axial stress at a pile head, $\sigma_{B}$ : concrete strength of a pile cap) under the condition that a pile cap isn't damaged with strength decrease, and an analytical method to judge the condition of its application.
\end{abstract}

Keywords : Pile foundation, Pile head joint, Precast concrete pile, Pile cap, Bearing stress, Seismic design 杭基礎, 杭頭接合部, 既製コンクリート杭, パイルキャップ, 支圧応力, 耐震設計

\section{1. 序論}

近年，杭頭とパイルキャップを半剛接合やピン接合とする杭頭 接合方法が実用化されている。杭頭を半剛接合やピン接合とする ことで, 地震時に作用する杭頭曲げモーメントを低減することが 可能となり, 杭基礎の耐震性能を向上させる有効な手段として普 及が進んでいる1)。現在実用化されている杭頭を剛接合としない接 合方法を大別すると，機械的なピンやローラー機構を備えた装置 を杭頭部に設置するタイプ(装置夕イプと称す)，および杭頭に特 殊な装置を用いずに在来工法の延長で杭頭半剛接合を実現する夕イ プ（非装置タイプと称す）に分けられる。装置タイプは地震時の軸 力変動が生じても比較的安定したピンやローラーの性能を保持する ことができるが，精密な施工と杭頭接合装置のコストが必要となる。 非装置夕イプは, 基本的に杭の主筋もしくは杭頭補強筋をパイル キャップに定着せず，杭頭へパイルキャップを載置するだけの構造 である。このため比較的に低コストで簡便に施工できるが軸力変動 の影響を受け易いため設計段階における十分な検討が必要となる11。

筆者らは，既製コンクリート杭の非装置夕イプの杭頭半剛接合法 の 1 つである改良型簡易接合法 ${ }^{2)}$ を提案している。改良型簡易接合 法とは1978 年以前に存在した補強鉄筋を用いずに杭頭部をパイル キャップに $100 \mathrm{~mm}$ 程度根入れする簡易的な杭頭接合法 ${ }^{3 \sim 5)}$ を改良し たもので，根入れした杭頭外周部に空隙を設けることで杭頭の回転 性能を向上させた杭頭接合法である。前報2) では一般的な支持力を 有する杭に改良型簡易接合法を採用した場合を想定し，最大で
$17.5 \mathrm{~N} / \mathrm{mm}^{2}$ までの軸応力下における杭頭の回転性状を静的構造実験 によって明らかにし，そのモデル化手法を示した。

しかしながら，既製コンクリート杭の施工分野では，近年，従来 の 2 倍以上の支持力を有するプレボーリング拡大根固め工法や中掘 拡大根固め工法など（以後, 高支持力杭と称す）が多数開発され, 普 及が進んでいる ${ }^{6)}$ 。高支持力杭の支持力は，地盤条件が良好であ机 ば，杭材の許容応力度で決定される。杭材には設計基準強度 105N/ $\mathrm{mm}^{2}$ のコンクリートが使用されることが多く, PHC 杭 C 種の場合，プ レストレスを差し引いた短期許容応力が $50 \mathrm{~N} / \mathrm{mm}^{2}$ となる。従って, 地盤と構造物の設計条件によるが，高支持力杭を採用した杭頭には， 中程度の地震時に $50 \mathrm{~N} / \mathrm{mm}^{2}$ 程度の軸応力が作用する可能性がある。

今回，高支持力杭に改良型簡易接合法を採用した際の杭頭接合部 の回転性状と損傷状況を把握することを目的とし, 最大で $60 \mathrm{~N} / \mathrm{mm}^{2}$ の軸応力下における静的構造実験を実施した。本報では，静的構造 実験の概要と構造性能に関する検討結果について報告する。

\section{2. 実験概要}

\section{1 改良型簡易接合法の概要}

図 2.1（a）に改良型簡易接合法の概要を示す2)。補強鉄筋を用 いずに，杭頭をパイルキャップヘ $50 \sim 100 \mathrm{~mm}$ 根入れし，根入れし た杭頭の外周部と基礎コンクリートおよび捨てコンクリートとの 境界面にテーパー状の空隙を設けたものである。この空隙によつ て, 根入れ深さや捨てコンクリートの厚さに依存しない, 安定し

\footnotetext{
*1 大成建設(株技術センター 主任研究員・修士 (工学

*2 大成建設株技術センター 副主任研究員・修士 (工学)

*3 大成建設(株設計本部 シニアエンジニア・修士 (工学)

*4 日本大学理工学部 教授. 工博
}

Senior Research Engineer, Technology Center, Taisei Corp., M. Eng.

Research Engineer, Technology Center, Taisei Corp., M. Eng.

Senior Engineer, Design Division, Taisei Corp., M. Eng.

Prof., College of Science \& Technology, Nihon Univ., Dr. Eng. 
た杭頭の回転性状を得ることが可能となる2)。パイルキャップの水 平力は, 杭頭部の摩擦抵抗と根入れ部のせん断抵抗によって杭へ 伝達される。ただし, 改良型簡易接合法は, 引抜き力に対する抵 抗要素がないため, 引抜き力が作用しないことが適用条件となる。 図 2.1 (b) に改良型簡易接合法の杭頭部が回転した状態を模式的 に示す。引張側の杭端部に浮き上がりが生じるとともに, 押し込 み側の杭端部はパイルキャップにめり込みが生じるものと考えら れる。この場合, パイルキャップと杭頭圧縮縁には軸力による支 圧応力が局所的に作用する。前報 ${ }^{2)}$ の実験結果から, 改良型簡易 接合法には, 支圧応力の増加によってパイルキャップと杭頭に損 傷が生じる可能性があることが示唆されている。

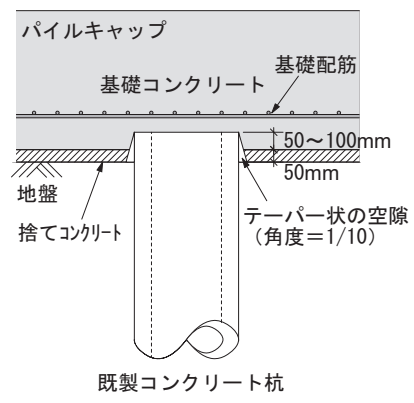

(a) 接合部の概要

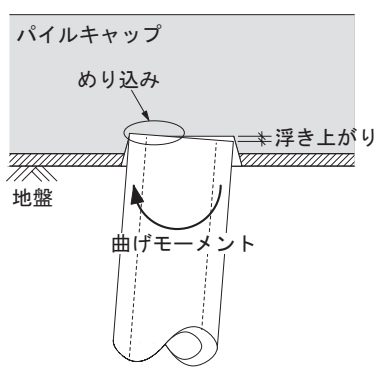

(b) 杭頭の回転状況
図2.1 改良型簡易接合法の概要

\section{2 試験体と実験ヶース}

試験体は, 実大スケールのパイルキャップと杭から構成されて いる。表 2.1 にパイルキャップ試験体の諸元を示す。図 2.2 にパ イルキャップ試験体の形状と配筋概要の一例を示す。パイル キャップ試験体は, へりあき寸法を変えて 3 種類 $(\mathrm{F} 1 \sim \mathrm{F} 3)$, 合 計 10 体作製した。へりあき寸法は, F $1<\mathrm{F} 2<\mathrm{F} 3$ の関係にあり, F2 $(H / D=0.75, H: へ り$ あき寸法, $D:$ 杭径 $)$ が一般的なパイルキャッ プ寸法を想定した試験体である。パイルキャップ試験体の中央部

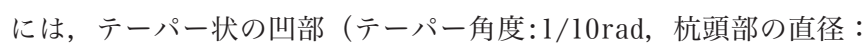
$303 \mathrm{~mm}$, 深さ: $50 \mathrm{~mm}$ ）を厚さ $1.2 \mathrm{~mm}$ の鋼製の捨て型枠を用いて設け ている。実験時に, この凹部に試験杭を鉛直に設置することで, 改 良型簡易接合法による杭頭接合部を構築した。パイルキャップの 配筋は, 基礎筋と帯筋ともD $13 @ 150 \mathrm{~mm}$ とし, 全ての試験体で共 通とした。表 2.1 には各試験体種類毎に実験当日におけるコンク リートの材料特性の平均值を示した。なお，パイルキャップ試験 体の作製は, 杭頭接合部のコンクリートの密実性を確保するため に, 実際の施工状況を模擬して, スタブを上部にしてコンクリー トを打設した。

表 2.2 に杭試験体の諸元を示す。図 2.3 に杭試験体の概要を示 す。杭試験体は, 種別を変えて 4 種類 $(\mathrm{P} 1 \sim \mathrm{P} 4)$, 合計 8 本作製 した。いずれの試験体も杭径 $300 \mathrm{~mm}$, 肉厚 $60 \mathrm{~mm}$, 杭長 $1750 \mathrm{~mm}$ で あり，杭頭から $1500 \mathrm{~mm}$ の位置に加力用のPC 鋼棒を設置した。杭 頭部に中詰めコンクリートは打設していない。P 1 は，パイル キャップの損傷限界と終局限界を把握するために作製した加力用 のSC 杭であり, 最大荷重に至っても杭が降伏しない仕様（SN490 材, 鋼管厚 $22 \mathrm{~mm}$ ) とした。P2〜P4 は, 杭頭部の損傷限界と終局 限界を把握するための試験杭である。P2 は, 設計基準強度 $85 \mathrm{~N} / \mathrm{mm}^{2}$ の PHC 杭 -C 種であり, 杭頭には端板と補強バンドが存在する。端
表2. 1 パイルキャップ試験体の諸元

\begin{tabular}{|c|c|c|c|c|c|c|c|}
\hline \multirow{2}{*}{ 名称 } & パ イルキャップ 寸法 & へりあき & \multirow[t]{2}{*}{$H / D$} & コンクリート強度 & ヤソグ 係数 & ポ アリツ比 & 数量 \\
\hline & $W \times B \times h(m m)$ & $H(\mathrm{~mm})$ & & $\sigma_{B}\left(\mathrm{~N} / \mathrm{mm}^{2}\right)$ & $E\left(\mathrm{~N} / \mathrm{mm}^{2}\right)$ & $\nu$ & 体 \\
\hline Fl-1 $\sim 3$ & $600 \times 600 \times 300$ & 150 & 0.50 & 38.5 & 31,467 & 0.23 & 3 \\
\hline F2-1 $\sim 3$ & $750 \times 750 \times 350$ & 225 & 0.75 & 37.0 & 30,167 & 0.23 & 3 \\
\hline F3-1 $\sim 4$ & $900 \times 900 \times 450$ & 300 & 1.00 & 37.3 & 30,100 & 0.22 & 4 \\
\hline
\end{tabular}

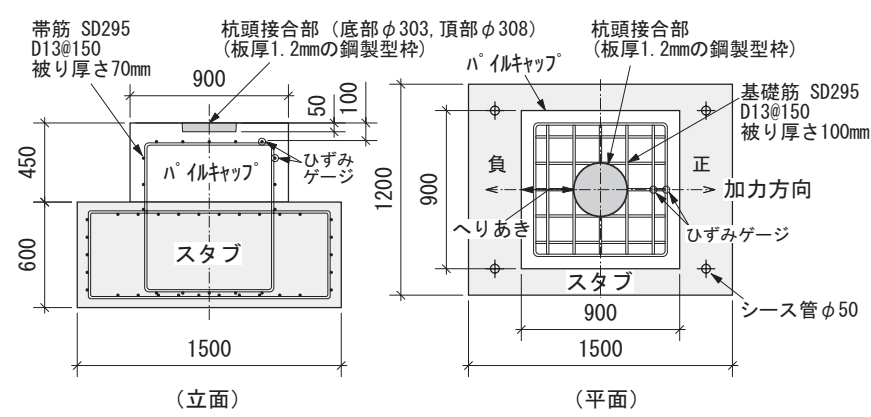

図2.2 パイルキャップ試験体の形状と配筋（F 3 試験体）

表2. 2 杭試験体の諸元

\begin{tabular}{|c|c|c|c|c|c|c|c|c|c|}
\hline \multirow{2}{*}{ 名称 } & \multirow{2}{*}{ 種別 } & \multirow{2}{*}{$\begin{array}{c}\text { 杭径 } \\
\mathrm{mm} \\
\end{array}$} & \multirow{2}{*}{\begin{tabular}{|c|} 
肉厚 \\
$\mathrm{mm}$ \\
\end{tabular}} & \multirow{2}{*}{$\begin{array}{l}\text { 補強 } \\
\Lambda^{*} \text { ・ }\end{array}$} & \multicolumn{4}{|c|}{ 強度ヤソグ 係类 } & \multirow{2}{*}{$\begin{array}{l}\text { 数量 } \\
\text { 本 } \\
\end{array}$} \\
\hline & & & & & $\sigma_{e}\left(\mathrm{~N} / \mathrm{mm}^{2}\right)$ & $\sigma_{\mathrm{B}}\left(\mathrm{N} / \mathrm{mm}^{2}\right)$ & $E\left(N / m^{2}\right)$ & $\nu$ & \\
\hline $\mathrm{Pl}$ & SC- t 22-Fcl20 & 300 & 60 & - & 0 & 118.9 & 37,434 & 0.21 & 1 \\
\hline P2-1 4 & PHC-C-Fc85 & 300 & 60 & 有り & 10 & 92.1 & 42,180 & 0.21 & 4 \\
\hline P3-1 2 & PHC-C-Fc105 & 300 & 60 & 有り & 10 & 118.4 & 44,492 & 0.22 & 2 \\
\hline P4 & PHC-C-Fc105 & 300 & 60 & 無し & 10 & 116.7 & 44,156 & 0.23 & 1 \\
\hline
\end{tabular}

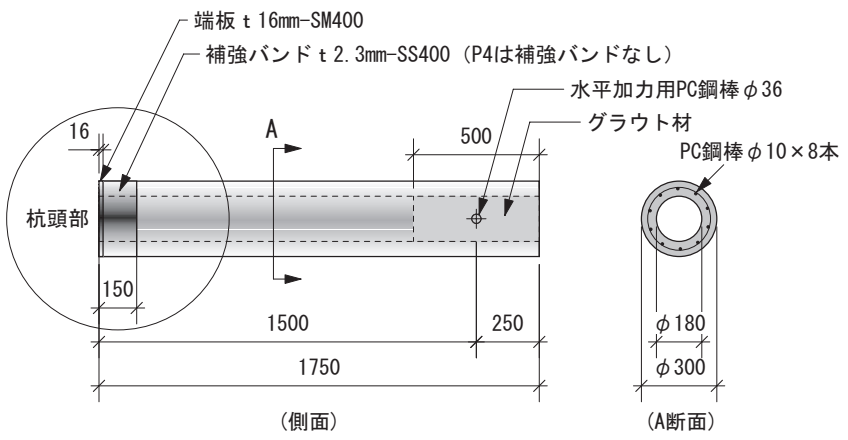

図2.3 杭試験体の概要（P2４試験体）

表2. 3 実験ケースの一覧

\begin{tabular}{|c|c|c|c|c|c|}
\hline \multirow{2}{*}{ シリーズ } & \multirow{2}{*}{ 実験N o. } & \multicolumn{2}{|c|}{ 試験体 } & 軸力 & 軸応力 \\
\hline & & 杭 & パ イルキャップ & $\mathrm{N}(\mathrm{kN})$ & $\sigma_{\mathrm{n}}\left(\mathrm{N} / \mathrm{mm}^{2}\right)$ \\
\hline \multirow{12}{*}{1} & 1 & \multirow{12}{*}{$\mathrm{Pl}$} & $\mathrm{Fl}-1$ & 900 & 20 \\
\hline & 2 & & Fl-2 & 1800 & 40 \\
\hline & 3 & & $\mathrm{Fl}-3$ & 2700 & 60 \\
\hline & 4 & & F2-1 & 900 & 20 \\
\hline & 5 & & F2-2 & 1800 & 40 \\
\hline & 6 & & F2-3 & 2700 & 60 \\
\hline & \multirow{4}{*}{7} & & \multirow{4}{*}{ F3-1 } & 225 & 5 \\
\hline & & & & 450 & 10 \\
\hline & & & & 680 & 15 \\
\hline & & & & 900 & 20 \\
\hline & 8 & & F3-2 & 1800 & 40 \\
\hline & 9 & & F3-3 & 2700 & 60 \\
\hline \multirow{10}{*}{2} & \multirow{4}{*}{10} & \multirow{4}{*}{ P2-1 } & \multirow{10}{*}{ F3-4 } & 225 & 5 \\
\hline & & & & 340 & 8 \\
\hline & & & & 450 & 10 \\
\hline & & & & 680 & 15 \\
\hline & 11 & P2-3 & & 900 & 20 \\
\hline & 12 & P2-4 & & 1350 & 30 \\
\hline & 13 & P3-1 & & 1350 & 30 \\
\hline & 14 & P3-2 & & 1800 & 40 \\
\hline & 15 & $\mathrm{P} 4$ & & 1800 & 40 \\
\hline & 16 & P2-2 & & 1800 & 40 \\
\hline
\end{tabular}


板の仕様は, 材質が SM 400, 厚さが $16 \mathrm{~mm}$ である。補強バンドは, 材質がSS400, 厚さ $2.3 \mathrm{~mm}$, 幅 $150 \mathrm{~mm}$ の縞鋼板である。P3 は設計 基準強度 $105 \mathrm{~N} / \mathrm{mm}^{2}$ の $\mathrm{PHC}$ 杭 $-\mathrm{C}$ 種であり, 端板および補強バンド の仕様は, P2 と同様である。P4 は, 補強バンドの効果を把握する ための試験杭であり, 補強バンドを設けていない。その他の仕様 はP 3 と同様である。表 2.2 には各試験体種別毎に実験当日におけ るコンクリートの材料特性の平均值を示した。

表 2.3 に実験ケースの一覧を示す。実験はパイルキャップに着 目したシリーズ 1 と杭頭部に着目したシリーズ 2 を実施した。シ リーズ 1 では，加力用のP1 杭を用い，パイルキャップの仕様（F1 〜 F3） と軸応力 $\left(5 \sim 60 \mathrm{~N} / \mathrm{mm}^{2}\right)$ をパラメータとして，9 ケースの 実験を行った。なお，実験 No.7では同一のパイルキャップを用い, 軸応力を変えて複数回の加力を行った。シリーズ 2 では, F 3 パイ ルキャップを用い，杭の仕様（P2〜 P4） と軸応力（5〜 40N/ $\left.\mathrm{mm}^{2}\right)$ をパラメータとして，7 ケースの実験を行った。実験N No. 10 では, 同一の杭を用い，軸応力を変えて複数回の加力を行った。

\section{3 加力方法と計測項目}

図 2.4 に加力方法の概要を示す。実験は，パイルキャップ試験 体を反力フロアーに固定し，杭試験体をパイルキャップに鉛直に 設置する。次いで, 軸力導入用の油圧ジャッキによって所定の一 定軸力を導入し，杭先端部分を 2 台のアクチュエータで水平に加 力した。杭先端の境界条件はピンローラーである。加力サイクル は，杭頭の回転角によって制御し，1 ステップ1サイクルの繰り 返し加力を基本とした。各試験体のステップ荷重は，予備解析結 果に基づき設定し，最大回転角で $50 \times 10^{-3} \mathrm{rad}$ 以上の加力を目標 とした。図 2.4 中に杭の曲げモーメント分布と加力サイクルの概 要を示す。主な荷重および変位量の計測項目は, 杭頭接合部の回 転角と鉛直・水平変位，アクチュエータの荷重と加力点の水平変 位, 軸力導入用ジャッキの荷重である。杭頭接合部の回転角は, 図 2.4 中に示すように水平加力軸方向の杭対面 2 点について鉛直変位 （杭の押し込み・引き抜き量）を測定し，この差を測定スパンで除 して求めた。主なひずみ量の測定項目は，パイルキャップの基礎 筋と帯筋のひずみ（図 2.2 参照）と杭頭の補強バンドのひずみ（図 2.4 参照) である。また, 加力ステップ毎に試験体のひび割れ発生 状況の観察とひび割れ幅の測定を行った。

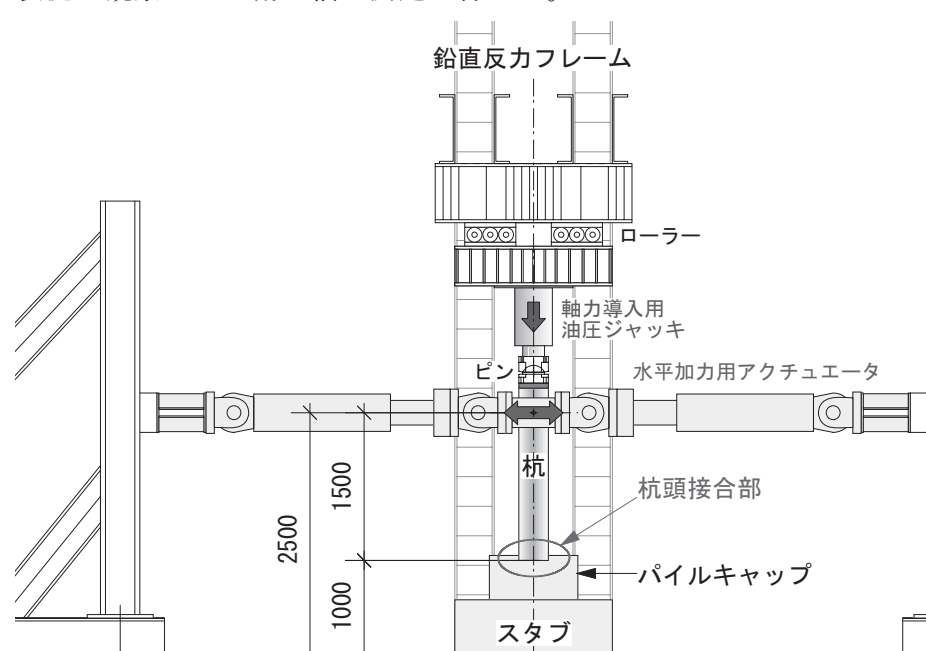

\section{3. シリーズ 1 の実験結果と考察}

\section{1 加力点の水平荷重〜水平変位関係}

図 3.1 に加力点の水平荷重 $P$ と水平変位 $\delta$ の関係を軸力 $N$ と水 平変位 $\delta$ の関係とともに例示する（No.7，8，9）。同図（a）より, 軸力は水平変位によらずほぼ一定に保持できていることが分かる。 同図 $(\mathrm{b}) \sim(\mathrm{d})$ には, 軸力と水平変位による $P-\delta$ 効果の影響（ $P-$ $\delta$ 効果: $N \times \delta^{\prime} / L, N$ : 軸力, $\delta^{\prime}:$ 杭先端のピン位置の水平変位, $L$ : 加力点から杭頭接合部までの距離）を併記した。各ケースの最 大水平荷重は軸力に依存して大きくなることが分かる。また，い ずれのケースも水平荷重は最大值に達した後, $P-\delta$ 効果の勾配に 対応して低下していることが分かる。このことから荷重低下の主 たる要因は $P-\delta$ 効果によるものと考えられる。

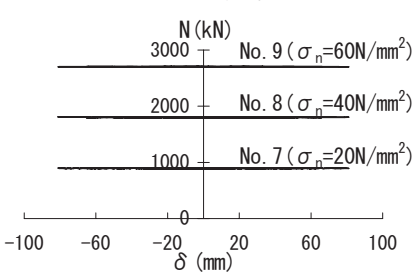

(a) 軸力〜水平変位の関係

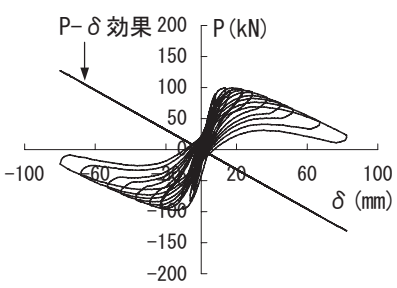

(c) No. 8 軸応力 $40 \mathrm{~N} / \mathrm{mm}^{2}$

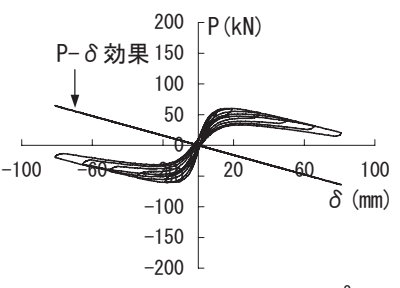

(b) No. 7 軸応力 $20 \mathrm{~N} / \mathrm{mm}^{2}$

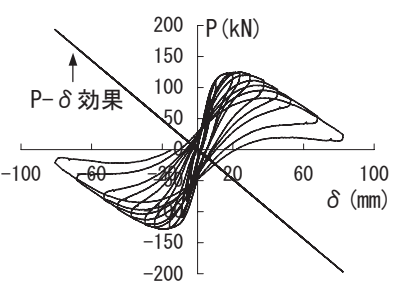

(d) No. 9 軸応力 $60 \mathrm{~N} / \mathrm{mm}^{2}$
図3.1 加力点の $N \sim \delta$ 関係，および $P \sim \delta$ 関係

\section{2 杭頭接合部の曲げモーメント〜回転角関係}

図 3.2 にシリーズ 1 における杭頭接合部の曲げモーメント $M$ と 回転角 $\theta$ の関係を例示する。シリーズ 1 では, パイルキャップの へりあき寸法と軸力が杭頭接合部の回転性状に与える影響に着目 しており，杭（P1）は弾性範囲内に収まっている。杭頭接合部の 曲げモーメントは, 水平荷重にスパンを乗じ, こ扎に軸力による 付加曲げモーメントを加算して求めた $\left(M=P \times L+N \times \delta{ }^{\prime}, P\right.$ : 水 平荷重)。同図には, 各ケースにおける最大偏心モーメント $M$ e

反カフロアー

図2.4 加力方法の概要 
$\left(M_{e}=0.5 N D, D:\right.$ 杭径 $)$ を併記した。 $M_{e}$ は, 試験体を剛体と仮定 したときの最大発生モーメント（浮き上がりモーメント）に相当 する。軸応力 $20 \mathrm{~N} / \mathrm{mm}^{2}$ の実験（No. 1，4，7）では, へりあき寸法 によらずほぼ同様の回転性状を示しており, いずれのケースも履 歴面積が小さい非線形弾性的な挙動を示している。また, 各ケー スの最大曲げモーメント $M_{\text {max }}$ は最大偏心モーメント $M_{e}$ に漸近して いる。軸応力 $40 \mathrm{~N} / \mathrm{mm}^{2}$ の実験（No.2，5，8）では, 軸応力 $20 \mathrm{~N} / \mathrm{mm}^{2}$ に比較して履歴面積が大きい。また, へりあき寸法 $(H / D)$ が小さ いほど履歴ループの膨らみが大きくなる傾向がある。いずれの ケースも $M_{\max }$ と $M_{e}$ の差が大きく, へりあき寸法が最も小さいNo. 2 （F1）では若干の耐力低下が生じている。軸応力 $60 \mathrm{~N} / \mathrm{mm}^{2}$ の実験 (No.3，6，9）では，これらの現象がより明瞭に認められる。また, へりあき寸法が小さいNo.3（F1）では, パイルキャップの破壊に より軸力低下を伴う曲げ耐力の低下が生じた。このため, 回転角 が約 $30 \times 10^{-3} \mathrm{rad}$ の段階で実験を終了した。

表 3.1 に $M_{\max }$ と $M_{e}$ の一覧を示す。図 3.3 に $M_{\max }$ と軸応力 $\sigma_{n}$ (軸 力 $N$ を断面積 $A$ で除した值）の関係を示す。同図には, $M_{e}$ と $\sigma_{n}$ の 関係 $\left(M_{e}=0.5 \sigma_{n} \cdot A \cdot D\right)$ を併記した。 $M_{\text {max }}$ は, 軸応力 $15 \mathrm{~N} / \mathrm{mm}^{2}$ 以 下では $M_{e}$ とほぼ一致している。しかし, $20 \mathrm{~N} / \mathrm{mm}^{2}$ 以上の軸応力で は, $M_{\max } / M_{e}$ が軸力の増加に応じて低下する傾向がある。この傾向

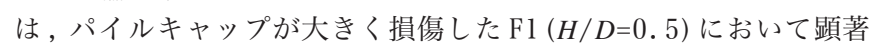
であるが，損傷の少ないF $3(H / D=1.0)$ においても認められる。前 報 ${ }^{2)}$ では, $17.5 \mathrm{~N} / \mathrm{mm}^{2}$ 以下の軸応力下において, 改良型簡易接合 法の $M_{\text {max }}$ が $M_{e}$ にほぼ一致することを示した。今回の実験によって, 高軸力下においては, $M_{\text {max }}$ が $M_{e}$ に達しないことが判明した。この
表3. $1 M_{m a x}$ と $M_{e}$ の一覧

\begin{tabular}{|c|c|c|c|c|c|}
\hline \multirow{2}{*}{ No. } & 試験体 & 軸応力 & 最大曲げモ-メ外 & 最大偏心モ-X冲 & \multirow{2}{*}{$\mathrm{M}_{\max } / \mathrm{M}_{\mathrm{e}}$} \\
\hline & $H / D$ & $\sigma_{\mathrm{n}}\left(\mathrm{N} / \mathrm{mm}^{2}\right)$ & $\mathrm{M}_{\max }(\mathrm{kN} \cdot \mathrm{m})$ & $\mathrm{M}_{\mathrm{e}}(\mathrm{kN} \cdot \mathrm{m})$ & \\
\hline 1 & \multirow{3}{*}{$\begin{array}{c}F 1 \\
H / D=0.5\end{array}$} & 20 & 123.0 & 135.5 & 0.91 \\
\hline 2 & & 40 & 196.2 & 272.9 & 0.72 \\
\hline 3 & & 60 & 239.4 & 407.1 & 0.59 \\
\hline 4 & \multirow{3}{*}{$\begin{array}{c}F 2 \\
H / D=0.75\end{array}$} & 20 & 128. 5 & 136.7 & 0.94 \\
\hline 5 & & 40 & 226.8 & 271.1 & 0.84 \\
\hline 6 & & 60 & 310.8 & 407.9 & 0.76 \\
\hline \multirow{4}{*}{7} & \multirow{6}{*}{$\begin{array}{c}F 3 \\
H / D=1.0\end{array}$} & 5 & 36.1 & 34.4 & 1.05 \\
\hline & & 10 & 68.9 & 68.7 & 1.00 \\
\hline & & 15 & 100.7 & 102.0 & 0.99 \\
\hline & & 20 & 128.0 & 137.1 & 0.93 \\
\hline 8 & & 40 & 231.0 & 271.5 & 0.85 \\
\hline 9 & & 60 & 330.6 & 407.3 & 0.81 \\
\hline
\end{tabular}

原因として，パイルキャップ 400 の変形に伴う幾何学的な要 因とパイルキャップの損傷 による耐力低下が考光られ る。なお, 軸応力 $5 \mathrm{~N} / \mathrm{mm}^{2}$ の $\stackrel{\times}{\underline{\underline{m}}}^{2} 100$ 実験では, $M_{\max } / M_{e}$ が 1.05 と なった。この理由として, 加 力装置の摩擦抵抗の影響が 考えられる。

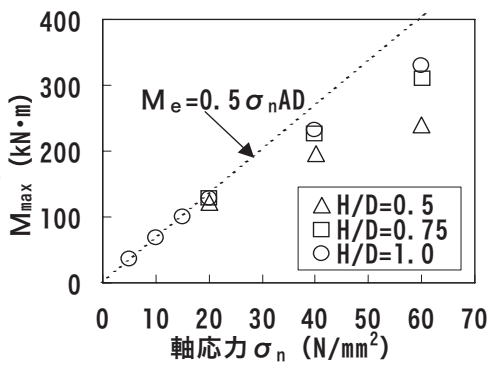

\section{3 パイルキャップの損傷状況}

図 3.4 にパイルキャップの最終ひび割れ状況，および基礎筋と 帯筋のひずみ $\varepsilon$ と回転角 $\theta$ の関係をあわせて示す（ひずみゲージ 貼付位置は図 2.2 を参照されたい)。また同図には, 最大ひび割れ

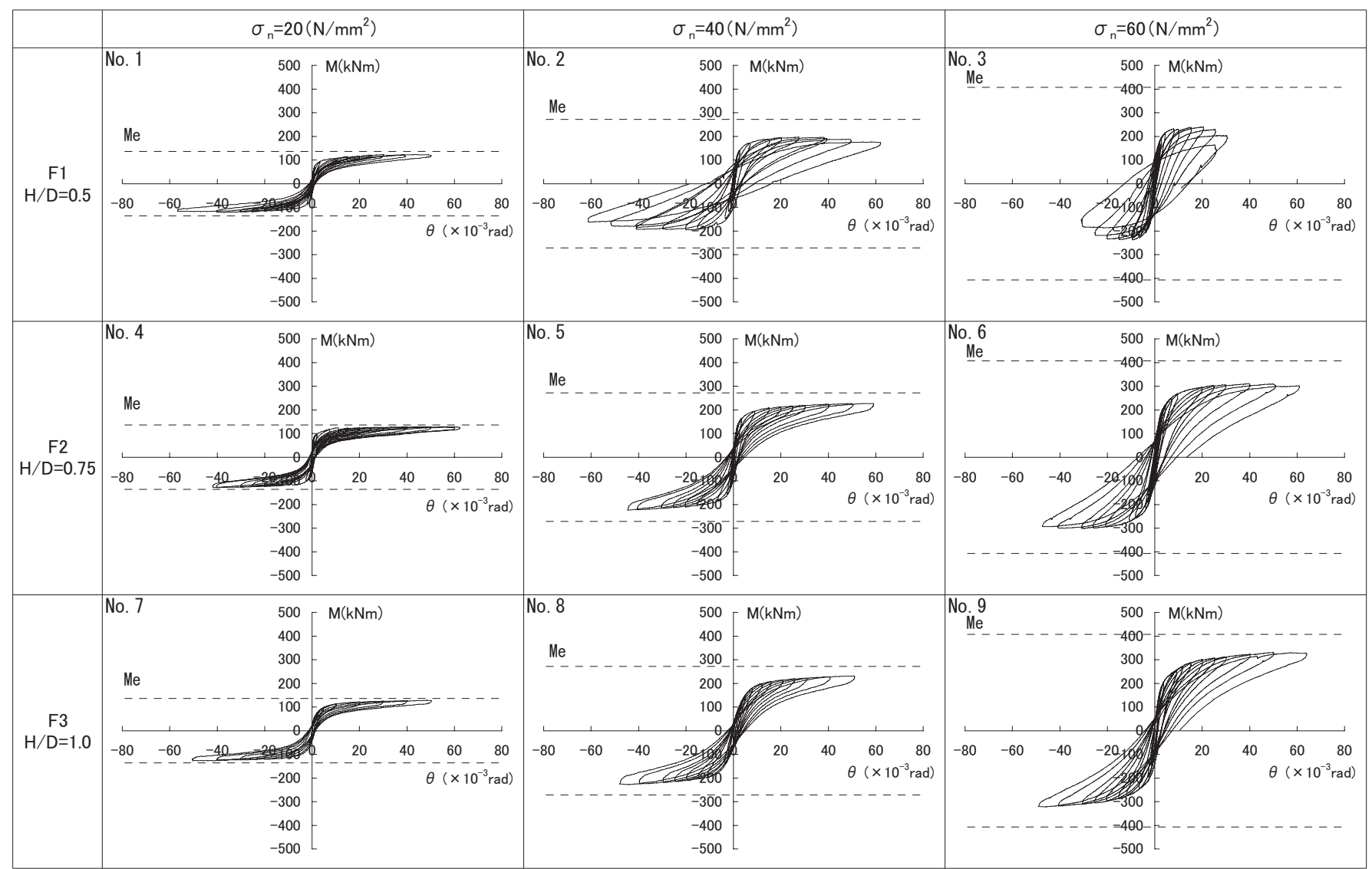

図3.2 杭頭接合部の曲げモーメント〜回転角関係（シリーズ 1) 


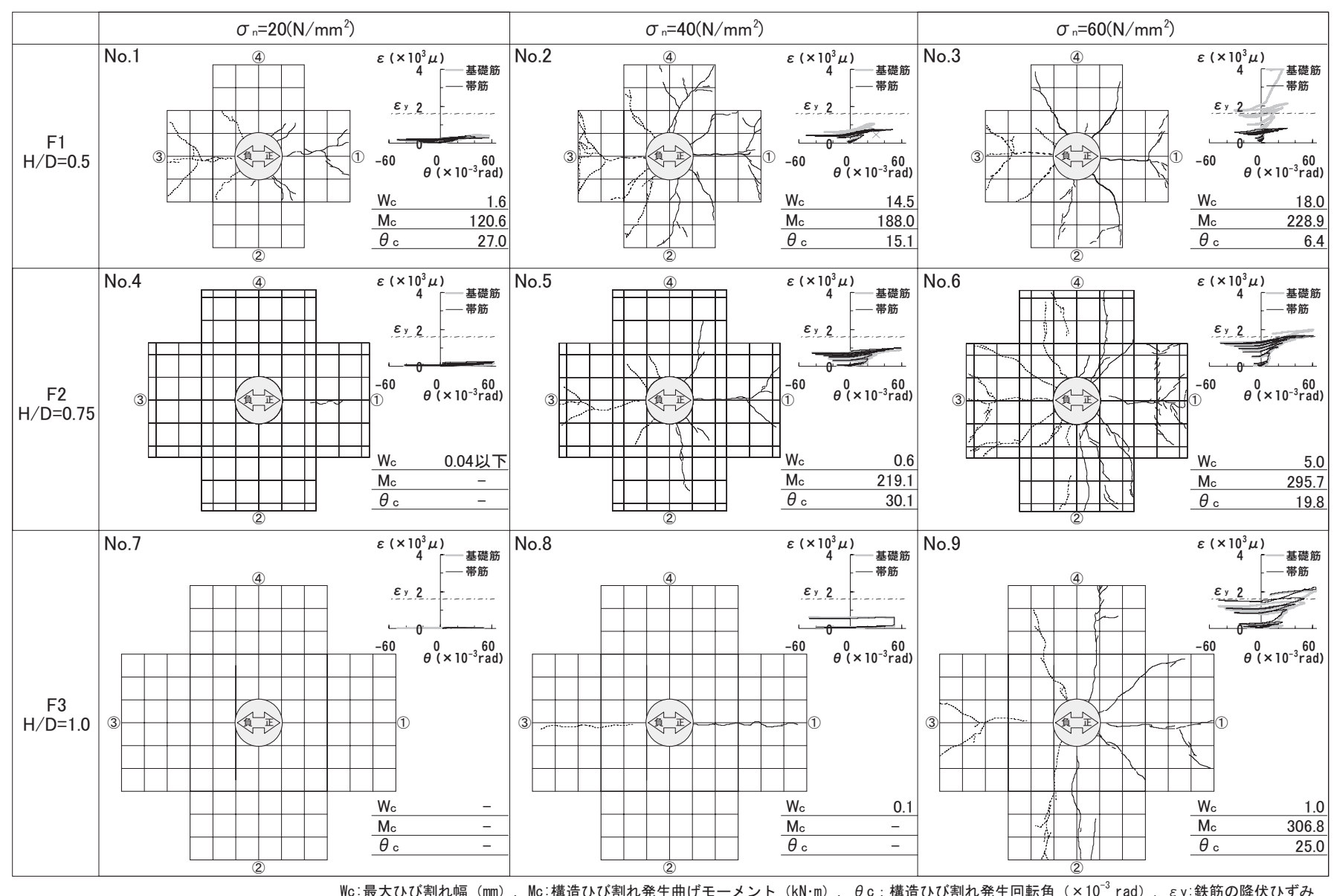

図3.4 パイルキャップの最終ひび割れ状況

幅 $W_{c}$, 構造ひび割れ発生時の曲げモーメント $M_{c}$ と回転角 $\theta_{c}$ を併 記した。ここで, 構造ひび割机は幅 $0.2 \mathrm{~mm}$ 以上のひび割れと定義 した。パイルキャップのひび割れ量とひび割れ幅は, 軸応力と杭 頭の回転角の大きさに対応して増加する傾向がある。このことか ら, パイルキャップの損傷の主たる要因は, 杭頭の回転と供に増 加する支圧応力によるものと考えられる。また, 同一の軸応力に おいては, へりあき寸法が小さいほど損傷が大きい。前節で示し た $M \sim \theta$ 関係の履歴ループの膨らみと $M_{\max } / M_{e}$ の低下傾向がパイ ルキャップの損傷状況に対応していることが分かる。基礎筋と帯 筋のひずみ量についてもひび割れの発生状況に対応している。

\section{4 パイルキャップの耐力評価手法の提案}

図 3.5 に $M_{\text {max }} / M_{e}$ と軸応力比 $\left(\sigma_{n} / \sigma_{B}, \sigma_{B}\right.$ : コンクリート強 度）の関係を示す。同図には, 前報2)で実施した杭径 $600 \mathrm{~mm}$ の実験 結果を併記した。実験デー夕は, 杭径が $300 \mathrm{~mm}$ と $600 \mathrm{~mm}$, へりあ き比が $0.33 \sim 1.0$, 軸応力比が $0.11 \sim 1.62$, パイルキャップの コンクリート強度が $25.7 \sim 41.7 \mathrm{~N} / \mathrm{mm}^{2}$ の 28 データである。この うち No. 2 と No. 3 については, パイルキャップの損傷により耐力 低下が生じている。図中にて, 耐力低下が生じていない 26 デー夕 について, 最小二乗法による一次回帰を行った。回帰直線の相関 係数は, 0.898 であり良い相関がみられる。 $M_{\max } / M_{e}$ は, パイル キャップの変形に伴う幾何学的な要因, および支圧やひび割れの 影響を受ける複雑な材料非線形性に依存すると考えられるが, パ イルキャップに耐力低下を伴う損傷が生じないことを条件とすれ ば， $M_{\max }$ は，式（1）によって簡便に評価できる。

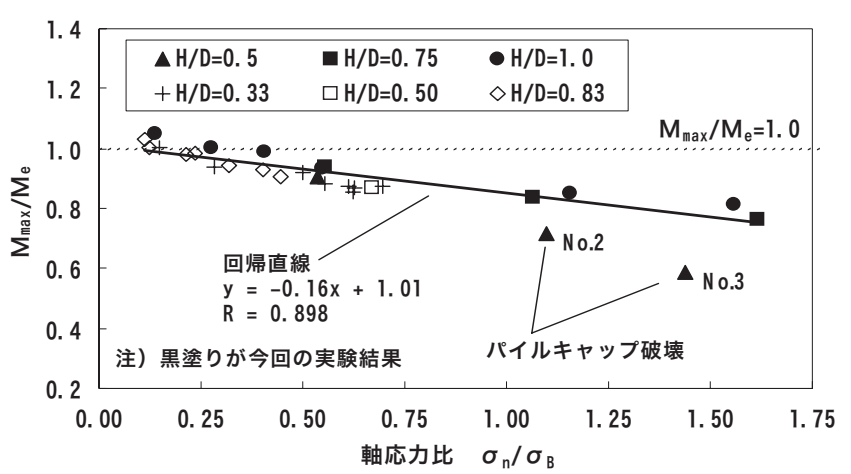

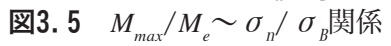

$$
M_{\max }=\alpha \cdot M_{e}
$$

ここで,

$\alpha$ : 実験による低減係数， $\alpha=-0.16 \sigma_{n} / \sigma_{B}+1.01 ，$ ただし， $\alpha \leqq 1.0$ $\sigma_{n}$ : 軸応力 $\left(\mathrm{N} / \mathrm{mm}^{2}\right), \sigma_{B}$ : コンクリート強度 $\left(\mathrm{N} / \mathrm{mm}^{2}\right)$ $M_{e}$ : 最大偏心モーメント, $M_{e}=0.5 N D(\mathrm{kN} \cdot \mathrm{m})$

$N$ : 軸力 $(\mathrm{kN}), D$ : 杭径 $(\mathrm{m})$

次に，パイルキャップが損傷しない条件について検討を行う。本 論では, 平面保持を仮定したパイルキャップ接合面の断面解析に より検討を行う。具体的には, 任意の軸力に対して杭頭接触面の 縁応力が支圧強度に達した時に損傷が生じると仮定し, この際の 曲げモーメント ${ }_{a} M_{c}$ を算定する。接触面の縁応力は, 杭頭の回転に 応じた支圧面積（接触面積）の減少とともに上昇する。一方, 支 圧強度も支承面積に対する支圧面積の減少に応じて上昇すること 
が知られており, 多数の評価式 が提案されている7)。ここでは, 最も一般的な式 (2) を用いて支 圧強度を算定する。この際，支 圧面積 $A_{0}$ については, 接触面の 形状に関わらず接触面積に等し いとし，杭頭圧縮縁から中立軸 位置 $x_{n}$ までの面積とする7)。ま

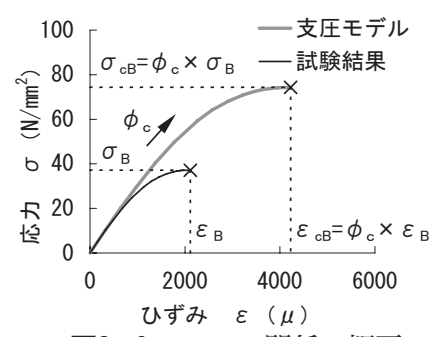

図3. $6 \sigma \sim \varepsilon$ 関係の概要

た, 支承面積 $A_{e}$ については, パイルキャップの全面積 $(\mathrm{a} \times \mathrm{b})$ を 有効とした場合，および偏心載荷の影響を考慮した式（3）による 支承面積 7) を用いた場合について比較検討する。コンクリートの 材料非線形性（ $\sigma \sim \varepsilon$ 関係）については, 図 3.6 に例示するよう に，圧縮強度試験で得られた応力〜ひずみ曲線に支圧係数 $\phi_{c}$ を乗 じて用いた ${ }^{8)}$ 。

$$
\sigma_{c B}=\phi_{c} \cdot \sigma_{B}
$$

ここで,

$$
\begin{aligned}
& \sigma_{c B} \text { : 支圧を考慮したコンクリート強度 }\left(\mathrm{N} / \mathrm{mm}^{2}\right) \\
& \sigma_{B} \text { : コンクリート強度 }\left(\mathrm{N} / \mathrm{mm}^{2}\right) \\
& \phi_{c} \text { : 支圧係数 }, \phi_{c}=\sqrt{A_{e} / A_{0}} \\
& A_{e} \text { : 有効支承面積 }\left(\mathrm{mm}^{2}\right), A_{0} \text { : 支圧面積 }\left(\mathrm{mm}^{2}\right)
\end{aligned}
$$$$
A_{e}=a^{\prime} \times b
$$

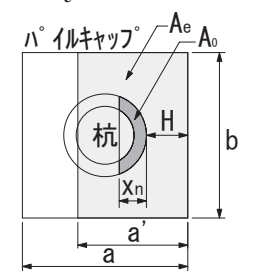

$a, b:$ パイルキャップ寸法 $(\mathrm{mm})$ $a^{\prime}:$ 偏心荷重による有効幅 $(\mathrm{mm})$

$a^{\prime}=x_{n}+2 H$

$x_{n}$ : 圧縮縁から中立軸までの距離 $(\mathrm{mm})$ $H:$ 完き法 (mm)

図 3.7 に解析によって得られた ${ }_{a} M_{c} \sim \sigma_{n}$ 関係を示す。同図 (a) は，支承面積をパイルキャップの全面積有効とした場合の結果で ある。同図（b）は, 偏心載荷の影響を考慮して, 支承面積を式 (3) によって求めた結果である。両図には, 実験によって得られた構 造ひび割机発生時の曲げモーメント $M_{c}$ を併記した。図中において, 白抜きのプロットは構造ひび割れが発生しなかったことを示して おり, 実験における最大值をプロットした。表 3.2 に解析結果と 実験結果の比較を示す。 ${ }_{a} M_{c}$ と $M_{c}$ の対応は, 偏心載荷の影響を考慮 した場合に比較して，支承面積を全面積有効とした場合の方が良 好 $\left(M_{c} / M_{c l}=0.95 \sim 1.21\right)$ である。一方, 偏心載荷の影響を考慮 した場合, 解析值は実験值を過小評価 $\left(M_{c} /{ }_{a} M_{c 2}=1.04 \sim 1.46\right)$ す るが, 設計的には安全側の結果が得られている。また， $\sigma_{n}=20 \mathrm{~N} /$ $\mathrm{mm}^{2}$ 未満の実験では, ${ }_{a} M_{c}$ を超える曲げモーメントを与えているが, 構造ひび割れは発生していない。構造ひび割れ発生時の曲げモー メントを精度良く評価するためには, より多くの実験デー夕が必 要と思われるが, 偏心載荷の影響を考慮した本解析手法によって, 少なくともパイルキャップに耐力低下を伴う損傷が生じない条件 を確保できるものと考えられる。

\section{4. シリーズ 2 の実験結果と考察}

\section{1 杭頭接合部の曲げモーメント〜回転角関係}

シリーズ 2 は杭頭の損傷に着目しており, パイルキャップには, へりあき寸法の最も大きな F3 $(H / D=1.0)$ の試験体を繰り返し用
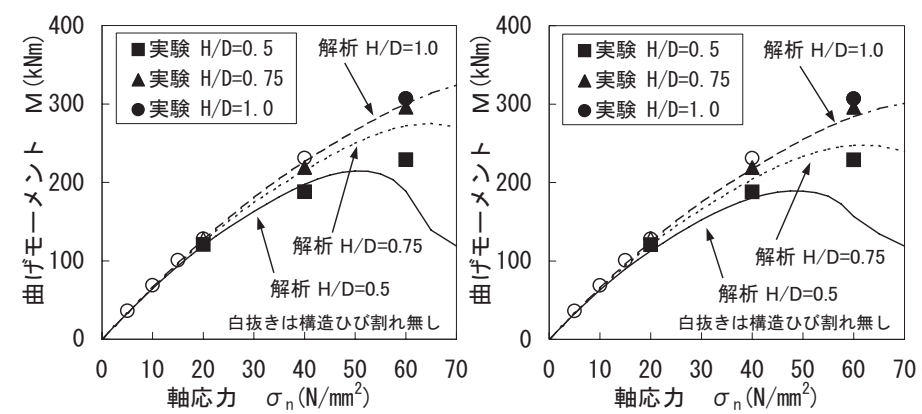

\begin{tabular}{|c|c|c|c|c|c|c|}
\hline \multirow[b]{2}{*}{ 試験体 } & \multirow{2}{*}{$\begin{array}{c}\text { 軸応力 } \\
\sigma_{\mathrm{n}} \\
\left(\mathrm{N} / \mathrm{mm}^{2}\right)\end{array}$} & \multirow{2}{*}{$\begin{array}{c}\text { 実験 } \\
\mathrm{M}_{\mathrm{c}} \\
(\mathrm{kN} \cdot \mathrm{m})\end{array}$} & \multicolumn{4}{|c|}{ 解析 } \\
\hline & & & $\begin{array}{c}{ }_{\mathrm{a}} \mathrm{M}_{\mathrm{cl}} \\
(\mathrm{kN} \cdot \mathrm{m})\end{array}$ & $\phi_{\mathrm{cl}}$ & $\begin{array}{c}{ }_{\mathrm{a}} \mathrm{M}_{\mathrm{c} 2} \\
(\mathrm{kN} \cdot \mathrm{m})\end{array}$ & $\phi_{\mathrm{c} 2}$ \\
\hline \multirow{3}{*}{$\begin{array}{c}F 1 \\
H / D=0.5\end{array}$} & 20 & 120.6 & $\begin{array}{l}119.6 \\
(1.01)\end{array}$ & 8.07 & $\begin{array}{c}112.8 \\
(1.07)\end{array}$ & 4.83 \\
\hline & 40 & 188.0 & $\begin{array}{c}197.4 \\
(0.95)\end{array}$ & 4. 70 & $\begin{array}{r}180.2 \\
(1.04)\end{array}$ & 3.56 \\
\hline & 60 & 228.9 & $\begin{array}{l}188.7 \\
(1.21)\end{array}$ & 3. 27 & $\begin{array}{l}156.8 \\
(1.46)\end{array}$ & 2. 90 \\
\hline \multirow{2}{*}{$\begin{array}{c}F 2 \\
H / D=0.75\end{array}$} & 40 & 219. 1 & $\begin{array}{l}215.1 \\
(1.02)\end{array}$ & 6.92 & $\begin{array}{l}204.1 \\
(1.07)\end{array}$ & 5.28 \\
\hline & 60 & 295.7 & $\frac{272.1}{(1.09)}$ & 5.33 & $\begin{array}{l}247.5 \\
(1.19)\end{array}$ & 4. 40 \\
\hline $\begin{array}{c}\mathrm{F3} \\
\mathrm{H} / \mathrm{D}=1.0\end{array}$ & 60 & 306.8 & $\begin{array}{l}300.2 \\
(1.02)\end{array}$ & 7. 26 & $\begin{array}{l}284.0 \\
(1.08)\end{array}$ & 5.97 \\
\hline
\end{tabular}

(a) $A=a \times b$ (全面積有効)

(b) $A_{e}=a^{\prime} \times b$ (偏心考慮 $)$

図3.7 $M_{c} \sim \sigma_{n}$ 関係の解析結果

表3. $2 M$ と $M_{c}, \phi$

いた。シリーズ 2 の全てのケースにおいて，パイルキャップにひ び割れは発生していない。図4.1-(a)〜 (f) にシリーズ 2 における 杭頭接合部の曲げモーメント $M$ と回転角 $\theta$ の関係を例示する。同 図には, 試験杭の短期許容曲げモーメント $M_{a}$ と終局曲げモーメン ト $M_{u}$ を併記した。 $M_{a}$ は, 杭コンクリートの設計基準強度 $F_{c}$ を用い て算定した規格值である。 $M_{u}$ は, 平面保持を仮定した断面解析に より，圧縮縁におけるコンクリートの軸応力が圧縮強度に達した 際の曲げモーメントとして算定した。ここで, 杭コンクリートの 材料非線形性については, 圧縮強度試験で得られた平均的な応力 〜ひずみ曲線を用いた。また，PC 鋼棒については，材料試験結果 から得られた降伏応力と引張耐力を用い, 応力〜ひずみ関係を卜 リリニアでモデル化して用いた ${ }^{9)}$ 。また, PHC 杭-C 種の有効プレ ストレス $\left(10 \mathrm{~N} / \mathrm{mm}^{2}\right)$ を考慮した。

軸応力 $20 \mathrm{~N} / \mathrm{mm}^{2}$ 以下の実験では, $M_{e}$ が小さいために $M_{\text {max }}$ は $M_{u}$ に 達することはなく $\left(M_{\max } / M_{u}=0.28 \sim 0.81\right)$, 最大 $67 \times 10^{-3} \mathrm{rad}$ 程 度の回転角まで安定した回転性状を示した（No. 10，11）。 $M \sim \theta$ 関係は, シリーズ 1 で得られた結果とほぼ同様である。軸応力 $30 \mathrm{~N} / \mathrm{mm}^{2}$ 以上の実験では, いずれのケースも杭頭部が曲げ圧壊を生 じ, 加力を終了した (No. 12〜 16)。ここで, 補強バンドのある P2 とP3の実験では, $M_{\max }$ が $M_{u}$ にほぼ達しており $\left(M_{\max } / M_{u}=0.97\right.$ $1.33)$, 補強バンドの上端にて曲げ压壊を生じた。一方, 補強バン ドのない $\mathrm{P} 4$ では, $M_{\max }$ が $M_{u}$ に達する前 $\left(M_{\max } / M_{u}=0.86\right)$ に杭頭 の圧縮縁が曲げ圧壊した。P4 と同一軸応力条件における P3 の $M_{\text {max }}$ は, P4 の約 1.28 倍となっており, 補強バンドが杭頭の曲げ圧壊抑 制に有効に作用しているものと考えられる。なお，軸応力 $10 \mathrm{~N} / \mathrm{mm}^{2}$ 以上の実験では， $M_{a}$ を超える曲げモーメントが作用しているが, 曲げ耐力や軸力保持能力の低下は生じていない。 


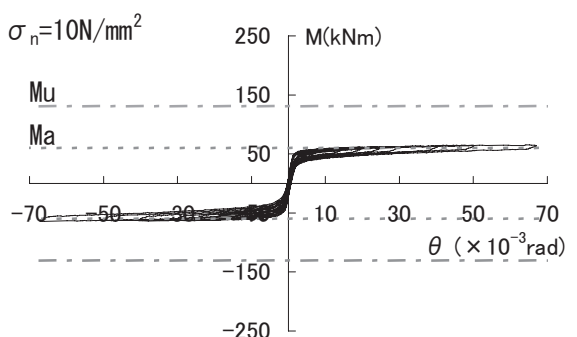

(a) No. 10 (P2-Fc85)

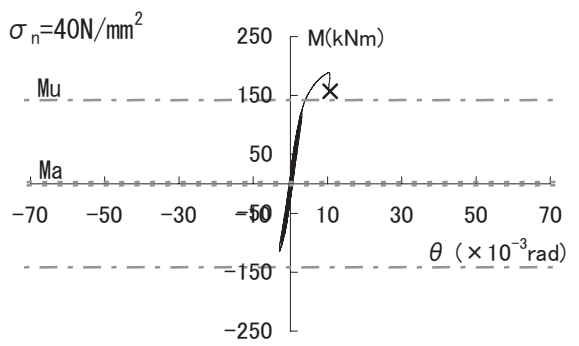

(d) No. 16 (P2-Fc85)

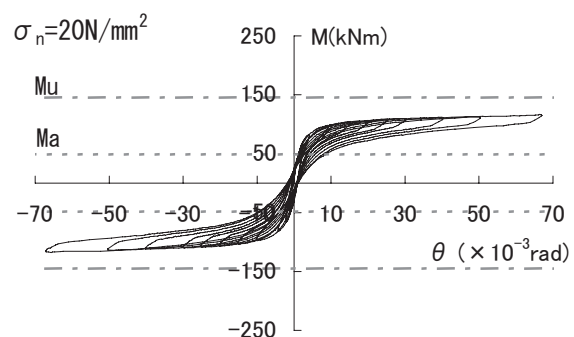

(b) No. $11(\mathrm{P} 2-\mathrm{Fc} 85)$

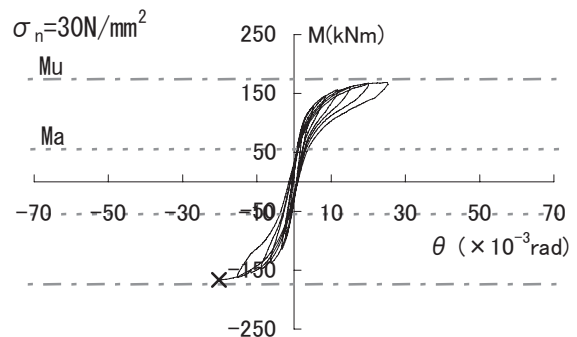

(e) No. 13 (P3-Fc105)

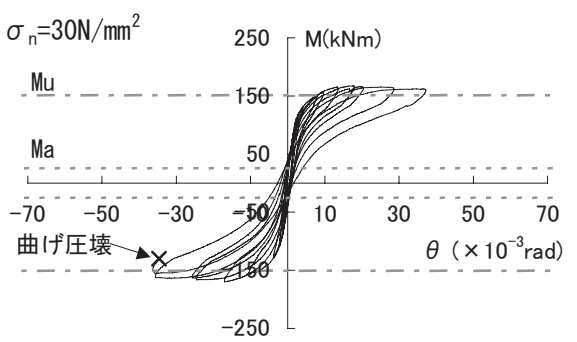

(c) No. 12 (P2-Fc85)

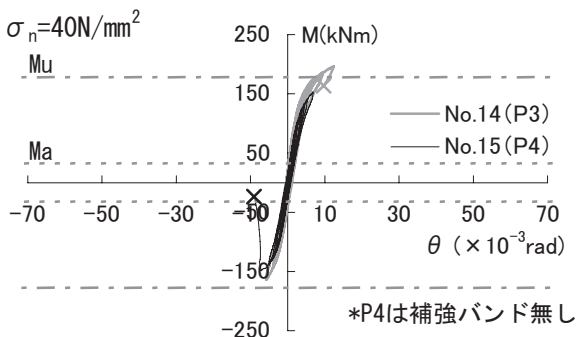

(f) No. 14,15 (Fc105)

図4.1 杭頭接合部の曲げモーメント〜回転角関係（シリーズ 2)

\section{2 杭頭の破壊性状と補強バンドのひずみ}

図 4.2 に杭頭の最終ひび割れ状況を示す。軸応力 $20 \mathrm{~N} / \mathrm{mm}^{2}$ 以下 の実験では，同図（a）に示すように杭頭部の補強バンド上端にお いてコンクリートの表層が若干剥落したが，構造ひび割れは発生 しなかった。軸応力 $30 \mathrm{~N} / \mathrm{mm}^{2}$ 以上の実験では，いずれのケースも軸 力の圧縮縁への集中に起因した曲げ圧壊を生じた。補強バンドの 無いP4 を除く試験杭では, 破壊荷重の 8 割以上の曲げモーメント が生じた際に圧縮側にてへアークラックが観測され，その後，補 強バンドの上部で曲げ圧壊を生じた（同図（b）〜 (e) 参照)。また， 軸応力 $30 \mathrm{~N} / \mathrm{mm}^{2}$ を与えた $\mathrm{P} 2$ の実験では, 比較的ひび割れ量が多く, 杭頭圧縮側の縦ひび割れに加え, 引張側の曲げひび割れが観測さ れた（同図（b）参照)。これに対して，P4では破壊荷重の 3 割程 度の曲げモーメントによって, 杭頭圧縮側にへアークラックが発 生した。その後, ヘアークラックの数が増加し, 杭頭圧縮縁にて 曲げ圧壊を生じた（同図（f）参照）。図 4.3 に補強バンドのひず みと回転角の関係を例示する (No. 12)。同図には，補強バンドの 降伏ひずみ $\varepsilon_{y}$ と杭コンクリートの圧縮強度試験から得られた破壊 ひずみの平均值 $\varepsilon_{B}$ を併記した。補強バンドは縞鋼板で作製されて いるため, 断面形状が位置によって異なる。このため, 各試験体 のひずみ測定結果にはばらつきが多く，ひずみ量を定量的に評価 することは困難であるが, 例示したケースでは, ひずみ量が $\varepsilon_{y}$ と $\varepsilon_{B}$ を超えている。これらの現象が曲げ圧壊したケースで多く見ら れることから, 補強バンドが杭頭部のコンクリートを拘束し, 曲 げ耐力を向上させていると考元られる。

\section{3 杭頭部の終局曲げモーメントに関する検討}

4.1 節で示した杭の終局曲げモーメント $M_{u}$ は, 杭軸部の終局曲 げモーメントである。しかし，改良型簡易接合法の杭頭接合面に おいては, 杭頭の端板がパイルキャップに定着されていないため, 断面の応力分布が杭軸部と異なる可能性がある。ここでは, 引張 力を負担しない改良型簡易接合法の杭頭接合面の終局曲げモーメ ント $M_{u}{ }^{\prime}$ を算定し, 実験結果との比較を行う。 $M_{u}{ }^{\prime}$ の算定は, 4.1 節で述べた平面保持断面解析によるが, 改良型簡易接合法の杭頭 接合面を想定し, 引張ひずみが発生した領域においてはプレスト
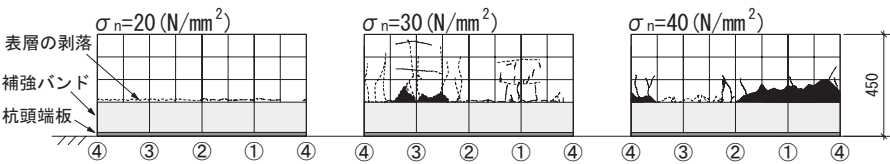

(a) No. 11 (P2-Fc85)

(b) No. 12 (P2-F 85$)$

(c) No. 16 (P2-Fc85)

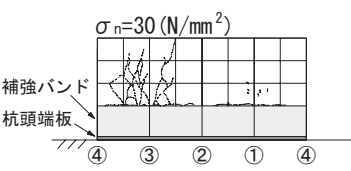

$\sigma_{\mathrm{n}}=40\left(\mathrm{~N} / \mathrm{mm}^{2}\right)$

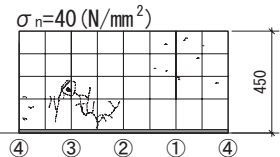

$\begin{array}{llll}\text { (d) No.13 } & \left(\mathrm{P} 3-\mathrm{F}_{\mathrm{c}} 105\right) & \text { (e) No. } 14 \quad\left(\mathrm{P} 3-\mathrm{F}_{\mathrm{c}} 105\right)^{\text {注) }} & \text { (f) No.15 (P4-F } 105)\end{array}$

注）№.14は，この状態の後に脆性的な曲げ圧壊を生じた。図中の(1) (4)は加力方向を示す (図2.4参照)

図4.2 杭頭の最終ひび割れ状況

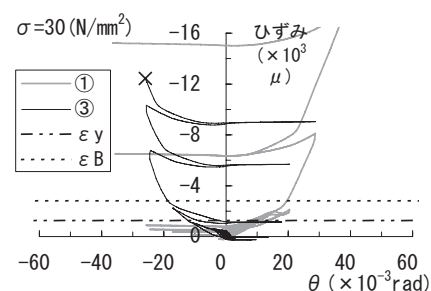

(a) 縦ひずみ

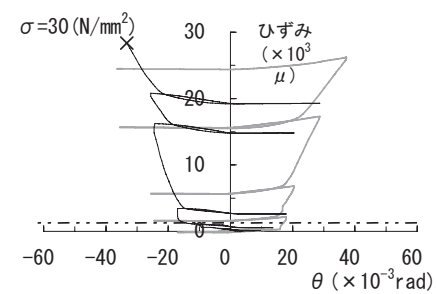

(b) 横ひずみ
図4.3 補強バンドのひずみと回転角の関係（No.12）

レス以外の応力を負担しない仮定を導入した。図 4.4 に終局曲げ モーメントに達した際の杭軸部断面, および杭頭接合面の応力と ひずみの分布を例示する $\left(\sigma_{n}=20 \mathrm{~N} / \mathrm{mm}^{2}\right.$ 時の結果 $)$ 。杭軸部の断面 では，圧縮縁から $138.3 \mathrm{~mm}$ の位置に中立軸が存在し，PC 鋼棒には 引張応力が作用している。これに対して, 引張応力を負担しない 杭頭接合面では，中立軸が圧縮縁から $98.2 \mathrm{~mm}$ の位置に存在し，引 張領域にはプレストレス以外の応力は作用していない。

図 4.5 にシリーズ 2 の実験で得られた杭頭接合面の最大曲げ モーメント $M_{\max }$, 破壊部の最大曲げモーメント $M_{B}(\mathrm{P} 2, \mathrm{P} 3$ では補 強バンド上端, P4 では杭頭接合面の最大曲げモーメント）と $\sigma_{n}$ の 関係を示す。同図には, 上述した $M_{u}$ と $M_{u}{ }^{\prime}$ おょび最大偏心モーメ ント $M_{e}$ を併記した。表 4.1 に実験結果と解析結果の比較を示す。 軸応力 $20 \mathrm{~N} / \mathrm{mm}^{2}$ 以下の実験（P2）では， $M_{\max }$ は $M_{e}$ に近い值となっ ており, シリーズ 1 の結果と対応している（図 3.3 参照）。また， $M_{\max }$ は $M_{u}{ }^{\prime}$ を超えている $\left(M_{\max } / M_{u}{ }^{\prime}=1.07 \sim 1.21\right)$ が，構造的な 
損傷は生じていない。軸応力 $30 \mathrm{~N} / \mathrm{mm}^{2}$ 以上の実験では, いずれも 杭が曲げ压壊したため, $M_{\max }$ と $M_{e}$ との差が大きい。P2（F $85 ）$ の 軸応力 $30 \mathrm{~N} / \mathrm{mm}^{2}$ 以上の実験では, $M_{\text {max }}$ は $M_{u}$ 'を大きく超え $\left(M_{\text {max }} /\right.$ $\left.M_{u}{ }^{\prime}=1.24 \sim 1.42\right)$, 補強バンドの上端において杭が曲げ圧壊し た。 $M_{B}$ と $M_{u}$ は比較的良い対応を示している $\left(M_{B} / M_{u}=1.01 \sim 1.21\right)$ 。 P3 $\left(F_{c} 105\right)$ も, P2 と同様に, $M_{\max }$ が $M_{u}{ }^{\prime}$ を超元 $\left(M_{\max } / M_{u}{ }^{\prime}=1.24\right.$ 〜 1.25), 補強バンドの上端において杭が曲げ圧壊した。ただし, $M_{B} / M_{u}$ は $0.89 \sim 1.02$ であり, 補強バンド上端の曲げ耐力が杭軸 部の曲げ耐力よりも低くなる可能性が認められる。一方, 補強バ ンドの無い P4 $\left(F_{c} 105\right)$ では, 杭頭接合面において杭が曲げ圧壊して おり, $M_{\text {max }}$ は $M_{u}{ }^{\prime}$ と良い対応を示した $\left(M_{\text {max }} / M_{u}{ }^{\prime}=0.98\right)$ 。

\section{5. 結論}

近年普及が進む高支持力杭に杭頭半剛接合法の 1 つである改良 型簡易接合法を採用した際の構造性能を実験的に検討し, 以下の 結論を得た。

（1）改良型簡易接合法を採用した杭頭接合部の最大曲げモーメン ト $M_{\text {max }}$ は, 低軸力下においては最大偏心モーメント $M_{e}$ にほぼ 一致するが, 高軸力下においては $M_{e}$ に達しない。パイルキャッ プに耐力低下を伴う損傷が生じないことを条件とすれば, $M_{\max } / M_{e}$ と軸応力比 $\left(\sigma_{n} / \sigma_{B}\right)$ の関係には良い相関が得られ る。このことから, $M_{e}$ と $\sigma_{n} / \sigma_{B}$ をパラメータとした $M_{\max }$ の 評価式を提案した。

（2）上記評価式の適用条件として, パイルキャップの寸法, コン クリート強度, 杭径, 軸力をパラメータとしたパイルキャッ プ接合面の断面解析手法を提案した。本解析手法に偏心載荷 の影響を考慮した支圧係数を導入することによって, パイル キャップに耐力低下を伴う損傷が生じないことを示した。

（3）改良型簡易接合法を採用した PHC 杭の破壊性状は, 高軸力下 においては, 軸応力の圧縮縁への集中に起因した杭頭部の曲 げ圧壊となる。補強バンドが無いP P HC 杭では, 杭頭圧縮縁が 曲げ圧壊したのに対し, 補強バンドのある PHC 杭では補強バ ンドの上端で曲げ圧壊を生じた。本実験の範囲では, 補強バ ンドによって曲げ耐力が約 1.28 倍に向上しており, 補強バン ドが杭頭の曲げ圧壊抑制に有効に作用している。

（4）補強バンドが無い PHC 杭に改良型簡易接合法を採用した場合 の杭頭接合面の曲げ耐力は, 引張応力を負担しない仮定を導 入した断面解析によって評価できる可能性を示した。補強バ ンドによる曲げ耐力の向上効果については, 今後さらに検討 していく必要がある。

\section{参考文献}

1) 建築コスト管理システム研究所: 杭頭半剛接合構法の調査報告, 建築コス 卜研究 2008 WINTER, pp.64-72, 2008. 1

2) 青島一樹, 島田博志, 小室 努:改良型簡易接合法を採用した既製コンク リート杭杭頭部の力学性状, 日本建築学会構造系論文集 第 607 号, pp. 125-132, 2006.9

3 ) 和智勝則, 浅野真一郎, 前田 昇, 青島一樹, 永井興史郎: 簡易接合法を 採用した既製コンクリート杭杭頭部の力学性状, 日本建築学会構造系論文 集 第570号,pp.85-91，2003.8

4 ）杉村義広, 平出 努: 高強度プレストレストコンクリート杭とパイル キャップ接合部の回転拘束度㧍よび破壊耐力に関する実験的研究, 日本建 築学会構造系論文報告集 第373号, pp.111-120, 1987.3
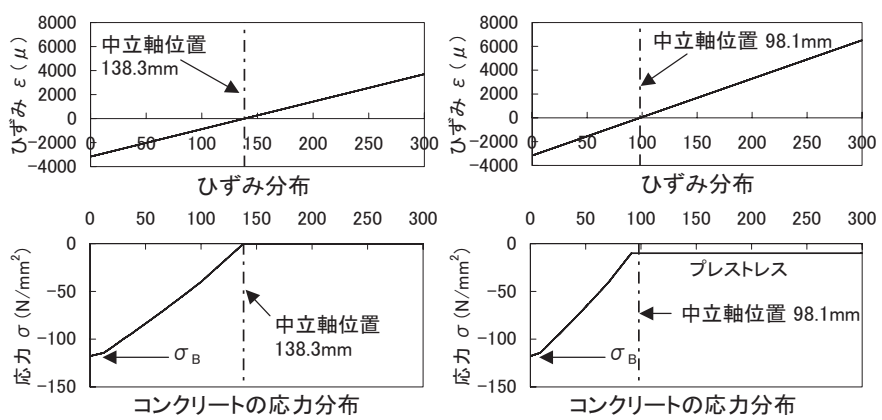

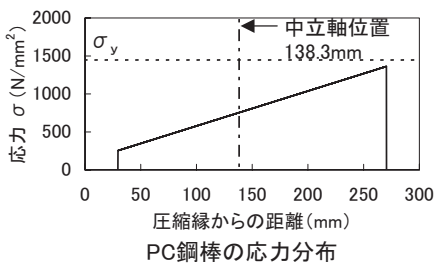

(a) 杭軸部断面 $\left(M_{\mathrm{u}}=162 \mathrm{kN} \cdot \mathrm{m}\right)$

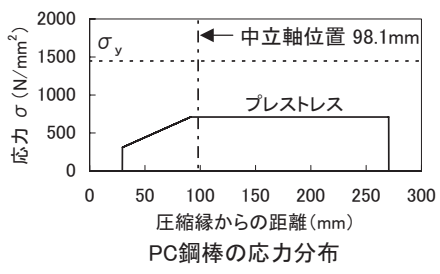

(b) 杭頭接合面 $\left(M_{\mu}{ }^{\prime}=102 \mathrm{kN} \cdot \mathrm{m}\right)$

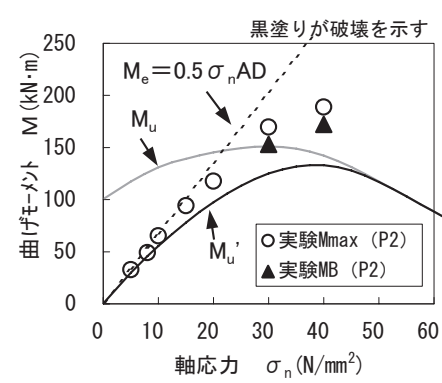

(a) P2 $\left(\mathrm{F}_{\mathrm{c}} 85\right)$

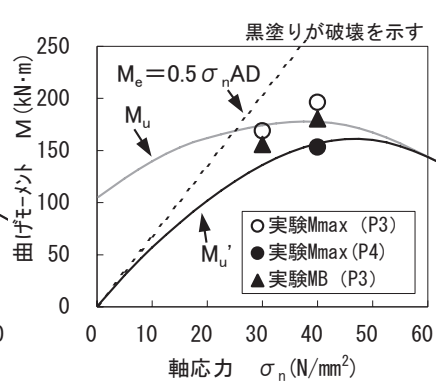

(b) P3, P4 ( $\left.F_{c} 105\right)$
図4. $5 M_{\max }, M_{B} \sim \sigma_{n}$ 関係

\begin{tabular}{|c|c|c|c|c|c|c|c|c|c|}
\hline \multirow[t]{2}{*}{ №. } & \multirow[t]{2}{*}{ 試験杭 } & \multirow{2}{*}{$\begin{array}{c}\text { 軸応力 } \\
\begin{array}{c}\sigma_{\mathrm{n}} \\
\left(\mathrm{N} / \mathrm{m}^{2}\right)\end{array}\end{array}$} & 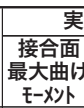 & 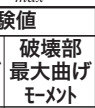 & 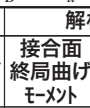 & 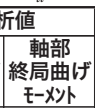 & \multicolumn{3}{|c|}{ 実験値/解析値 } \\
\hline & & & $\begin{array}{r}\mathrm{M}_{\max } \\
(\mathrm{kN} \cdot \mathrm{m})\end{array}$ & $\begin{array}{c}\mathrm{M}_{\mathrm{B}} \\
(\mathrm{kN} \cdot \mathrm{m})\end{array}$ & $\begin{array}{c}\mathrm{M}_{\mathrm{u}}^{\prime} \\
(\mathrm{kN} \cdot \mathrm{m})\end{array}$ & $\begin{array}{c}\mathrm{M}_{\mathrm{u}} \\
(\mathrm{kN} \cdot \mathrm{m})\end{array}$ & $\mathrm{M}_{\max } / \mathrm{M}_{\mathrm{u}}$ & $\mathrm{M}_{\max } / \mathrm{M}_{\mathrm{u}^{\prime}}$ & $\mathrm{M}_{\mathrm{B}} / \mathrm{M}_{\mathrm{u}}$ \\
\hline \multirow{4}{*}{10} & \multirow{7}{*}{$\begin{array}{c}\text { P2 } \\
(\mathrm{F} C 85)\end{array}$} & 5 & 32.7 & - & 30.0 & 117.4 & 0.28 & 1.09 & - \\
\hline & & 8 & 49.1 & - & 45.8 & 126.0 & 0.39 & 1.07 & - \\
\hline & & 10 & 65.3 & - & 55.6 & 130.9 & 0.50 & 1. 17 & - \\
\hline & & 15 & 94.2 & - & 78.0 & 139.3 & 0.68 & 1.21 & - \\
\hline 11 & & 20 & 117.6 & - & 97.5 & 145.3 & 0.81 & 1. 21 & - \\
\hline 12 & & 30 & 169.7 & 153.1 & 125.1 & 151.0 & 1.12 & 1.36 & 1.01 \\
\hline 16 & & 40 & 189.0 & 172.2 & 133.0 & 142.2 & 1.33 & 1.42 & 1.21 \\
\hline 13 & \multirow{2}{*}{$\begin{array}{c}\text { P3 } \\
\text { (Fc105) }\end{array}$} & 30 & 168.8 & 155.8 & 136.2 & 174. 1 & 0.97 & 1.24 & 0.89 \\
\hline 14 & & 40 & 196.2 & 180.4 & 156.8 & 177.7 & 1.10 & 1.25 & 1.02 \\
\hline 15 & $\begin{array}{c}\text { P4 } \\
\text { (Fc105) }\end{array}$ & 40 & 153.4 & 153.4 & 156.8 & 177.7 & 0.86 & 0.98 & 0.86 \\
\hline
\end{tabular}

5）杉村義広, 平出 努:高強度プレストレストコンクリート杭の杭頭接合部 の構造性能に関する研究, 建築研究報告 No. 112 , 建設省建築研究所, 1987.3

6) 桑原文夫, 他 : 特集: 高支持力杭の現状と課題, 基礎工 Vol. 36, No. 12, pp. 2-92, 総合土木研究所, 2008. 12

7）日本建築学会：鉄筋コンクリート終局強度設計に関する資料, pp . 34, pp. 90-100, 1987.9

8） 今井和正, 是永健好, 瀧口克己:めり込みを考慮した $\mathrm{RC}$ 部材端部の回転変 形解析法, 日本建築学会構造系論文集 第 562 号, pp. 99-105, 2002. 12

9) 日本道路協会: 道路橋示方書・同解説 IV 下部構造編, pp. 410-413, 2002.3 